\title{
LNG の地下岩盤内空洞貯蔵における空洞の安定性の検討

\author{
A STUDY OF STABILITY AROUND UNDERGROUND OPENINGS \\ EXCAVATED IN ROCK MASS DUE TO STORAGE OF LNG
}

\author{
稲 田 善 紀*・北 村 聖 一** ・ 岡 田 明 浩*** \\ By Yoshinori INADA, Shoichi KITAMURA and Akihiro OKADA
}

\section{1. 緒}

液化天燃ガス (LNG) は周知のとおり $-162^{\circ} \mathrm{C}$ とい ら極低温であるので, 最近では安全性・耐震性を考虑し て半地下式貯蔵槽も多く用いられるよらになった。しか しこの 貯蔵法は防災上埋め立て地等に 広大な敷地を要 し，海に対する環境問題等の規制の厳しい今日，必ずし も得策とはいえず，しかも国土の狭いわが国においては 土地の立体的な有効利用を考えねばならぬ時勢となって いる.

著者も数年前から LNG の地下岩盤内空洞への貯蔵 に関し基礎的な研究を進めてきている ${ }^{1) \sim 6)}$. 本論文では LNG を地下岩盤内に設けた円形空洞に直接貯蔵した場 合を想定し，まず，空洞周辺の非定常の温度分布を要素 分割法 ${ }^{3), 6)}$ を用いて計算し，さらにこれに基づき，時間 的に変化する熱応力等から逐次破壊を考慮に入れた空洞 周辺の応力解析を行い, 空洞の安定性について検討した 結果について述べる.

\section{2. 空洞周辺の温度分布}

\section{（1）温度分布の計算方法}

現在実用化されている半地下式貯蔵方式における地盤 中の温度分布の解析方法には差分法および有限要素法等 が用いられてきている7 。差分法は, (1) 解析法が明快で ある. (2) FEM に比べて適切な時間間隔の選定が容易 である等の長所はあるが, 形状が複雑な場合は, 境界条 件が煩雑となる等の短所があるといわれている7)・これ に対し 有限要素法は, (1) 複雑な形状の 境界条件を処理

* 正会員 工博 愛媛大学助教授 工学部土木工学教室

** 正会員 工修（株）阪神コンサルタンツ調査部第一課

*** 学生会員 愛媛大学大学院修士課程
できる. (2) 複合材の 解析に有効等の 長所はあるが, 分 割要素寸法と時間間隔を適切に選定することが必要など の欠点をもっているといわれている7).

本論文では, LNG の貯蔵によって発生する空洞周辺 の温度分布を非定常の熱伝導問題として扱い, 微小体積 内の熱収支を考慮したシュミットの方法 ${ }^{8)}$ を応用した要 素分割法 ${ }^{3)}$,6) を用いて計算することを試みた。要素分割 法は，(1) 解析法が単純明快である. (2) FEM に比べ時 間間隔の選定が比較的容易である. (3) 複雑な形状を処 理できる. (4) 複合材の解析に有効である. (5) 材料の熟 定数が温度とともに不規則に変化しても容易に対忘で きる. (6) 境界条件が時間とともに変化しても容易に対 応できる．等前述の 2 方法の長所を合わせてもってい る.このほか, 特に岩石のように金属と違って非常に熱 伝導の悪い物質は初期の時間には数 $\mathrm{mm}$ 単位で温度が 極端に異なるので温度分布を求める場合はある程度メッ シュを細かくとって正確に知る必要がある. しかも刻々 変化するのでそれらを追跡するには計算量が非常に多く なる. そこで温度分布がまだ及んでいない領域では計算 を打ち切って次の時刻の温度分布の計算に移る等の措置 が必要である.したがって有限要素法のようにすべての 要素についてのつり合い方程式を解く必要がなく, 任意 の個々の要素で計算を打ち切れる点で要素分割法は非常 に都合がよい。

ここでは空洞周辺を矩形要素ならびに三角形要素に分 割することにより温度分布を求め, これらの比較を行ら とともに厳密解との比較をも行い要素分割法の妥当性を 検討した。

a) 矩形要素分割の場合

図一1に示すように空洞周辺を 矩形要素で 分割する と, 任意の時間における任意の要素の温度は次式で与え られる6).

$$
U_{m, n+1}=\frac{1}{C\{A+(m-1) B\}}[(C-2)
$$




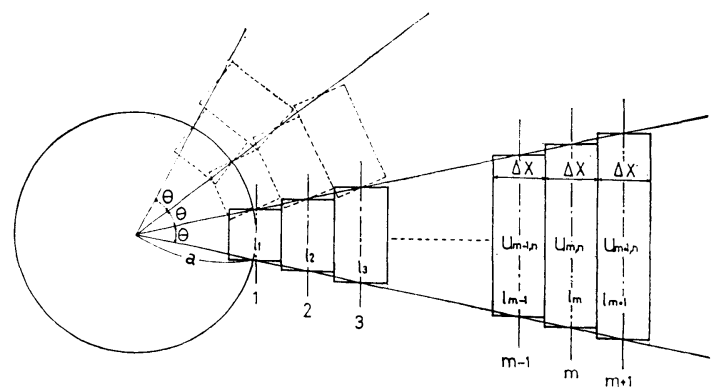

図一1 要秦分割法の説明図（矩形要素分割の場合）

- $\{A+(m-1) B\} U_{m, n}+(A+m B) U_{m+1, n}$

$\left.+\{A+(m-2) B\} U_{m-1, n}\right]$

ここで, $m \geqq 2, A=a \sin (\theta / 2), B=\Delta X \tan (\theta / 2)$,

$C=\Delta X^{2} / K \cdot \Delta \tau$

ただし, $U_{m, n}$ : 要素 $m$ における時刻 $n$ の温度

$a:$ 空洞半径, $\theta:$ 中心角, $m:$ 要素番号

$\Delta X:$ 分割要素間隔, $\Delta \tau:$ 分割時間間隔

$n:$ 任意の時間

$n+1: n$ より $\Delta \tau$ だけ後の時間

$K:$ 熱拡散率

なお，式（1）は円周方向の 温度差がなく，同心円的

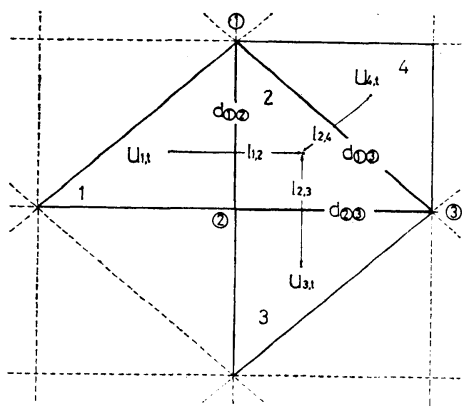

図一2 要紊分割法の説明図（三角形 要素分割の場合)

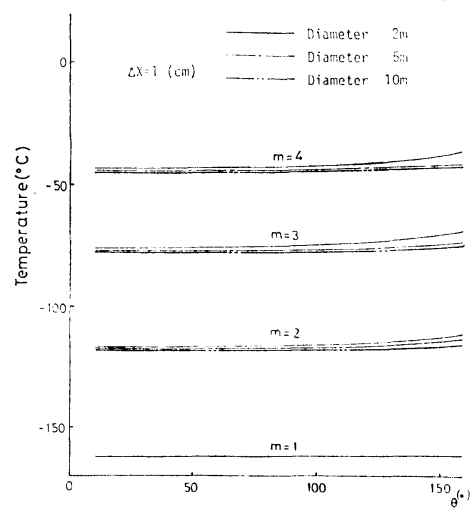

（a） 10 分後の場合

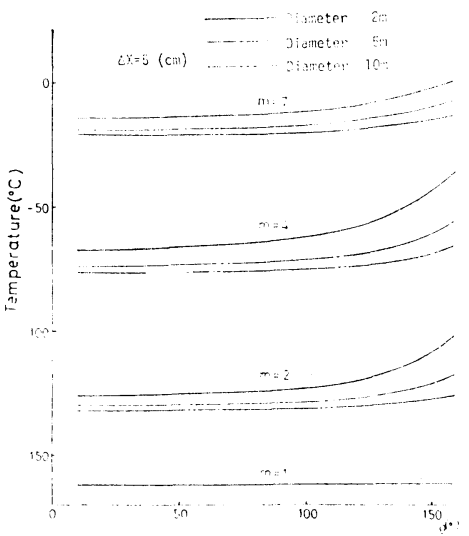

（b） 10 時間後の場合
図一3 $\theta$ を変化させた場合の各要秦の中心温度
に温度分布が広がってゆくと仮定した場合に適用できる 式で, 地表あるいは他の空洞から影響を受ける場合等, 別の境界条件を考慮せねばならない場合には適用できな い.

b) 三角形要素分割の場合

前述のとおり矩形要素分割が適用できない場合は要素 の形状を三角形にすることによって温度分布を計算する ことができる．この場合 図一2 に示すように，符号を とると要素 2 の任意の時間における温度は次式で与え られる6)。

$$
\begin{aligned}
U_{2, t+1}= & U_{2, t}+\frac{K}{S_{2}} \Delta \tau\left\{\frac{U_{1, t}-U_{2, t}}{l_{1,2}} d(1)(2)\right. \\
& \left.+\frac{U_{4, t}-U_{2, t}}{l_{2,4}} d \text { (2)(4) }+\frac{U_{3, t}-U_{2, t}}{l_{2,3}} d \text { (2)(3) }\right\}
\end{aligned}
$$

ただし (1), (2), (3)… : 各三角形要素の節点番号 ; 1.2 . $3 \cdots$ : 各三角形の要素の番号 $; U_{1, t}, U_{2, t}, U_{3, t} \cdots$ : 任意 の時間 $t$ における各要素の温度 $; l_{1,2}, l_{2,3}, l_{2,4} \cdots$ : 各要 素の 重心間距離 ; $d_{(1)(2)}, d_{(2)(3)}, d(2) \cdots$ : 各辺の長さ; $S_{1}, S_{2}, S_{3} \cdots$ : 各要素の面積

なお，式（2）は隣接する要素の重心間を結ぶ直線と 辺とが直交するかまたはこれに非常に近い場合に成立す る式であるので，要素の分割に際してはできるだけ正三 角形か直角三角形に近い三角形に分割する必要がある.

\section{（2） 温度分布の計算結果および考察}

矩形要素分割の場合の式 (1) を用いて温度分布を計算 するとき, 精度上問題 となるのは中心角の大きさ $(\theta)$, 要素の間隔 $(\Delta X)$ および時間間隔 $(\Delta \tau)$ である。まず $\theta$ については, LNG の気化温度である $-162^{\circ} \mathrm{C}$ を表面温 度とし, 空洞の直径 $2,5,10 \mathrm{~m}$ の各場合について $\Delta X$, $\theta$ を種々に変化させた場合の各要素の中心温度の時間的 変化を求めたが，このうち代表例を 図一3 (a)，(b) に示 した.これらの結果を総合して判 断すると, どの要素においても, また, 空洞の直径にかかわらず $\theta$ $=30^{\circ}$ 以下であればほとんど精 度上影響がないことがわかっ $た^{3)}$.ここでは念のため $\theta=15^{\circ}$ と して計算している. 次に $\Delta X=1$ $\mathrm{cm}$ とし, 空洞の直径 $2,5,10 \mathrm{~m}$ の各場合について無次元化した $C=\Delta X^{2} / K \Delta \tau$ の值を種々に変化 させた場合の分割要素の中心温度 の変化を求めた.このうち代表例 として $K=8.0 \times 10^{-3}\left[\mathrm{~cm}^{2} / \mathrm{s}\right]$ の ものを図一-4(a), (b) に示した。 同様に $\Delta X=10 \mathrm{~cm}$ の場合につい 


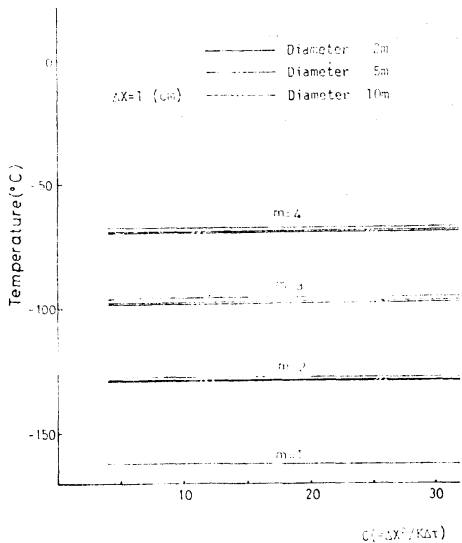

（a） 20 分後の場合

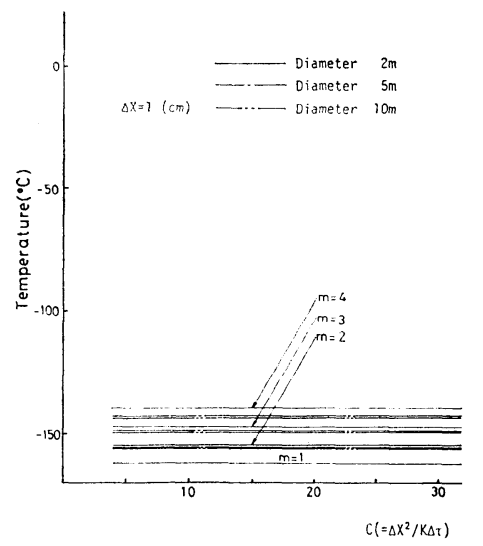

（b） 600 分後の場合

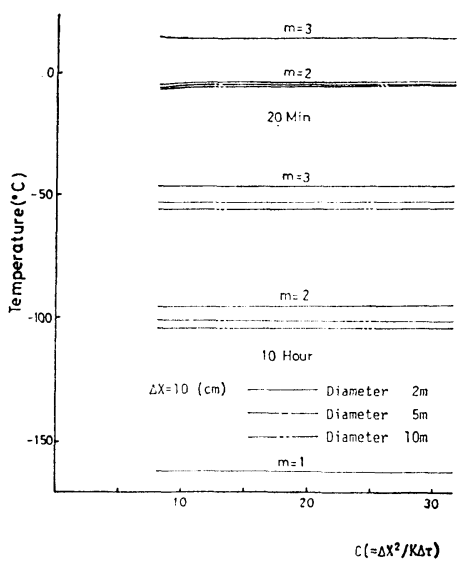

（c） 20 分, 600 分後の場合

\section{図一4 C を変化させた場合の各要素の中心温度}

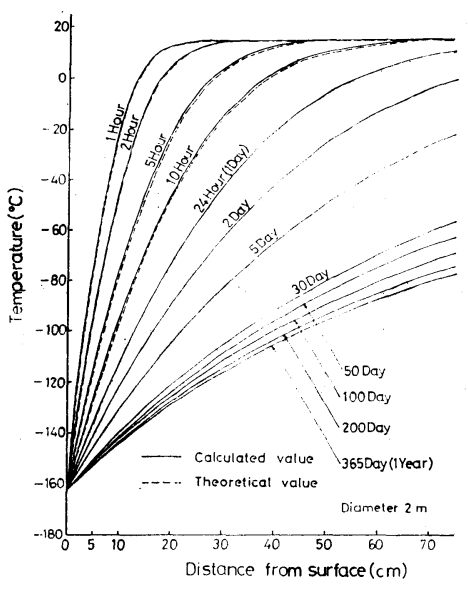

（a）空洞直径 $2 \mathrm{~m}$ の場合

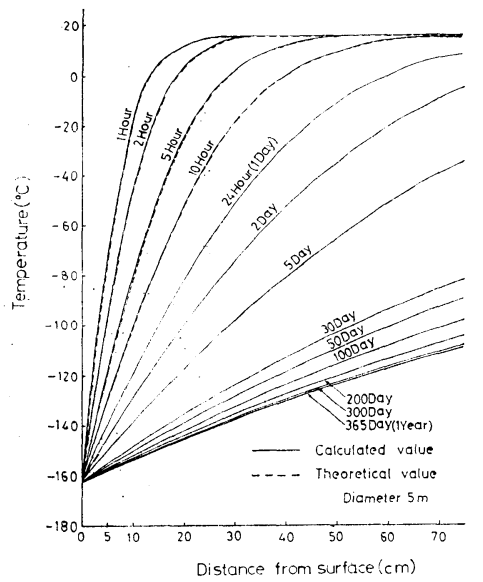

（b）空洞直径 $5 \mathrm{~m}$ の場合

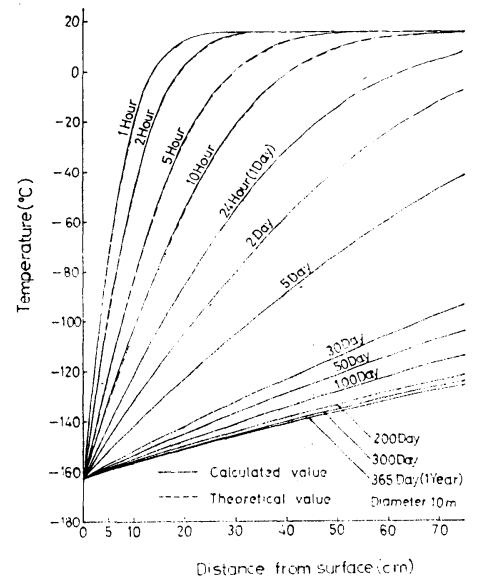

（c）空洞值径 $10 \mathrm{~m}$ の場合

\section{図一5 空洞周辺の温度分布の時間的変化}

て求めたものが (c) である.これらの図からわかるよう に, $C \geqq 10$ 以上ではほとんど 温度は収束して, 精度上 問題がないことがわかるが，ここでは念のため $C=20$ として計算している.

以上の基礎事項をふまえ，新鮮で亀裂のない花崗岩の 岩盤中の地下 $100 \mathrm{~m}$ の位置に直径 $2,5,10 \mathrm{~m}$ の円形空 洞を設けこの空洞内に LNG を貯蔵した場合を想定し， 空洞周辺の温度分布を求め(ここでは便宜上初期温度を すべて $15^{\circ} \mathrm{C}$ としている) とりまとめたものが図一15(a), (b)，(c) である.ただし，水平方向には温度分布に影響 を及ぼさない十分な広がりをもつ地山を想定している. また，実際には地下水の影響によって岩盤は湿潤状態に あると考えられる、したがって头結現象等によって状態 が変化し, その変化に熱量が消費され, 結果として熱伝 導が悪くなるなど, いわゆるステファン問題 ${ }^{12)}$ を考慮し なければならない，本論文ではこれらを考慮し，湿潤状 態の岩石について, みかけの熱拡散率を別の実験結果か
ら得ており，ここでは $K=11.0 \times 10^{-3} \mathrm{~cm}^{2} / \mathrm{s}$ の值 ${ }^{5)}$ を用 いて計算した.

これらの図からわかるように，初期の時間には空洞の 直径いかんにかかわらず,急激な温度勾配を示しており， また温度分布もさほど大きな違いがみられないが，時間 の経過とともに温度勾配は緩やかとなり，特に直径の大 きいほど同じ時間においてより遠くまで温度の影響が及 んでいる.また温度変化は時間とともに緩慢となり,約 1 年後ではほぼ集定常の状態になっていることがわかる.

一方，空洞周辺の非定常の温度分布を求めるための稂 密解は次式で与えられる ${ }^{8)}$.

$$
\begin{aligned}
U= & u_{0}+\frac{2}{\pi}\left(u_{0}-u_{1}\right) \int_{0}^{\infty} e^{-K u^{2} t} \\
& \cdot \frac{J_{0}(u r) Y_{0}(u a)-J_{0}(u a) Y_{0}(u r)}{J_{0}^{2}(u a)+Y_{0}^{2}(u a)} \frac{d u}{u}
\end{aligned}
$$

ただし, $u_{0}$ : 熱源温度, $u_{1}$ : 伝熱媒体の初期温度 $K:$ 熱拡散率, $t:$ 時間, $a:$ 空洞の半径 


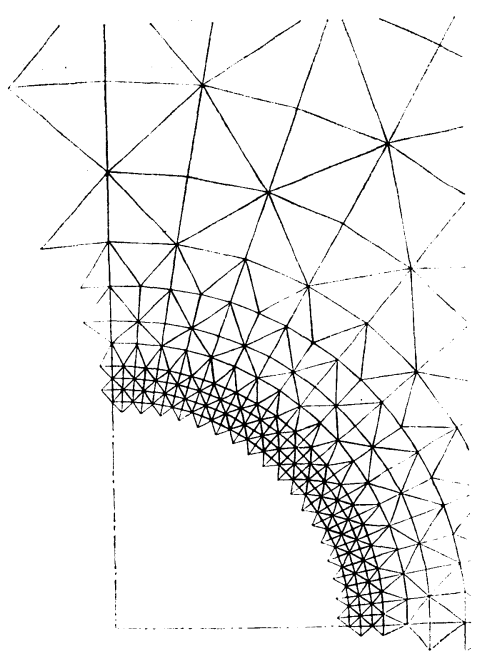

图一ー 三角形要菜による空洞周辺の分割の例

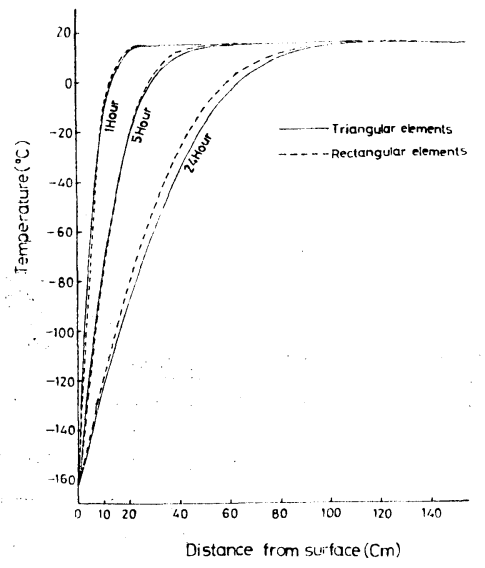

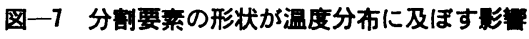

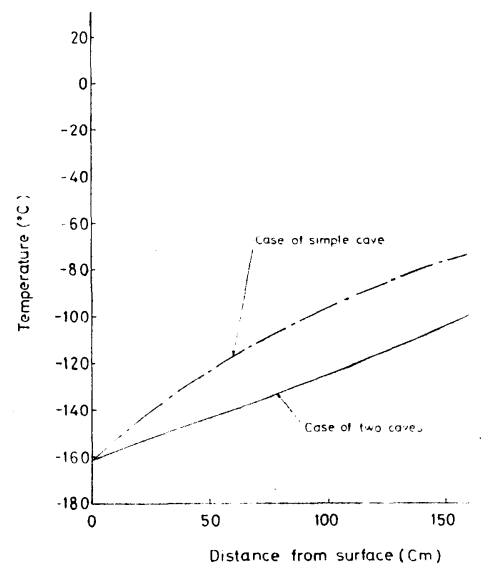

因一8 単一空洞と双設空洞の温度分布の比校

$J_{0}, Y_{0}: 0$ 階ベッセル関数

式 (3) 初期の時間においては次式で近似される

$$
\begin{aligned}
U= & u_{1}+\frac{\left(u_{0}-u_{1}\right) a^{1 / 2}}{r^{1 / 2}} \operatorname{erfc} \frac{r-a}{2 \sqrt{K t}} \\
& +\frac{\left(u_{0}-u_{1}\right)(r-a) \sqrt{K t}}{4 a^{1 / 2} r^{3 / 2}} i \operatorname{erfc} \frac{r-a}{2 \sqrt{K t}} \\
& +\frac{\left(u_{0}-u_{1}\right)\left(9 a^{2}-2 a r-7 r^{2}\right) K_{t}}{32 a^{3 / 2} r^{5 / 2}} l^{2} \mathrm{erfc} \\
& \cdot \frac{r-a}{2 \sqrt{K t}}+\ldots \ldots \ldots \ldots \ldots \ldots \ldots \ldots \ldots \ldots \ldots \ldots \ldots
\end{aligned}
$$

式（4）を用いて計算した結果を 図一5(a)〜 (c) に破 線で示し, 前述の要素分割法により得た結果とを比較し

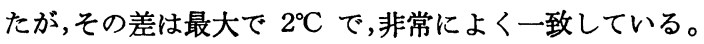

ここで，空洞周辺を前述の 図一1に示したような矩 形要素で分割した場合と, 図一6に示すような三角形要 素で分割した場合の分割形状の違いが温度分布に及ぼす 影響を直径 $5 \mathrm{~m}$ の空洞の場合について調べたものが 図 一7である. 時間の経過とともに両者には少しずつ差が 現われ，三角形要素の方が精度が少し落ちるが, 空洞の 数が複数の場合や形状が複雑な場合あるいは地表の境界 条件を考慮せねばならない場合には三角形要素を用いざ るを得ない。

さて, ここで要素分割法を用いて種々の場合の温度分 布を求めてみる.

まず，空洞が複数の場合について考える、いま，直径 $5 \mathrm{~m}$ の空洞を水平方向に直径の 5 倍（空洞表 面間 距 離 $25 \mathrm{~m}$ ) 離して双設空洞とした場合を想定し，この場合の 温度分布を単一空洞のそれと比較したものが図一8であ る. 空洞表面から $1 \mathrm{~m}$ の位置における温度差は約 $30^{\circ} \mathrm{C}$ あり, 双設空洞の中間点 $(12.5 \mathrm{~m})$ における温度差は $4^{\circ} \mathrm{C}$ であることから, 両者にはかなりの温度分布の差が あることがわかる. なお, 単一空洞の 1 年後の温度分布 から（図一5(b) 参照）低温の影響が及ばない最小距離 は空洞の表面から約 $17 \mathrm{~m}$ であることがわかった.

次に, 実際の LNG 貯蔵槽には内壁に液密および気

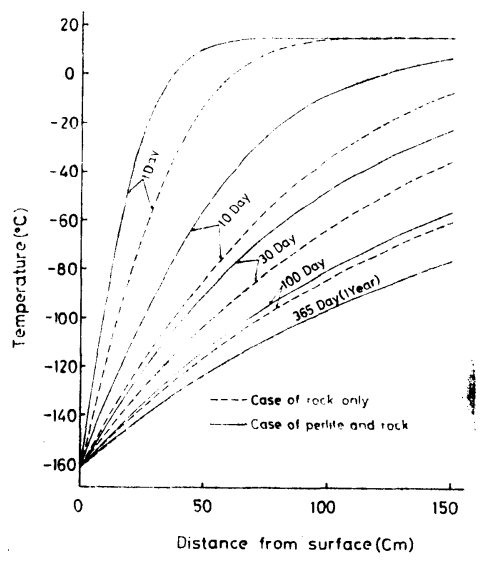

図一9 空洞周辺に $1 \mathrm{~m}$ の保命材の買を設け た埥合の温度分布 


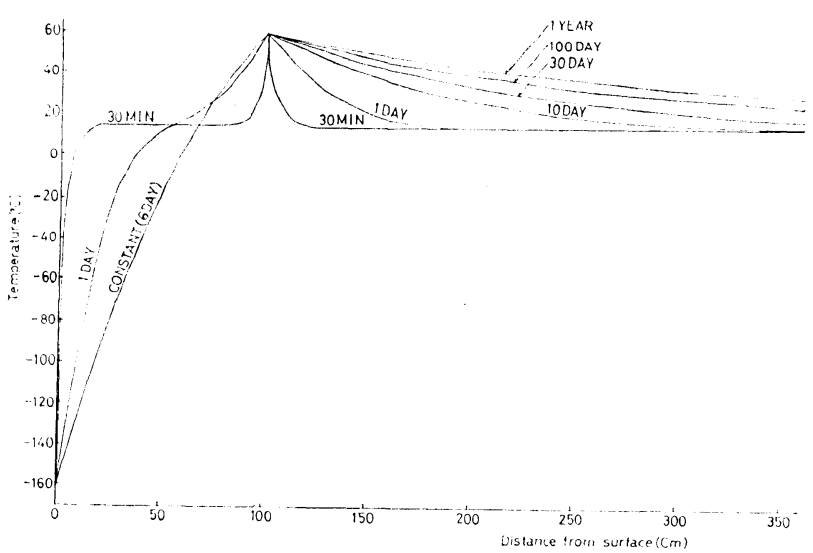

図一10 空洞周辺 $1 \mathrm{~m}$ を岩粉屈とし，岩盤との境界に $60^{\circ} \mathrm{C}$ のヒータを設けた场合の温度分布

密のため, しかも低温において脆性破壊を起こさない 2 $\sim 3 \mathrm{~mm}$ 程度の薄い金属（メンブレン）を使用し，その 外側に保冷材としてパーライトを使用したものがある. ここでも空洞の周辺に厚さ $1 \mathrm{~m}$ のパーライト粉の層を 設けた場合を想定して温度分布を求めたものが図一9で ある(ここではパーライト粉の層の 熱拡散率の值を $K$ $=2.8 \times 10^{-3} \mathrm{~cm}^{2} / \mathrm{s}$ として計算した).この図から, 約 30 日後までは保冷材の効果がよく現われているが，1 年後 には岩盤のみの場合と一致してしまうことがうかがえ る.

次に極低温が岩盤内に伝導するのを防止する目的で空 洞の周辺に人工的に岩粉を満たした層を $1 \mathrm{~m}$ 設け，そ の層と岩盤との境界に $60^{\circ} \mathrm{C}$ のヒーターを設けた場合を 考える.この場合の温度分布を理論的に求めたものが図 -10 である. $1 \mathrm{~m}$ 以内では 6 日後から 定常状態になる ことがらかがえる.ただし，ヒータ一設置によるボイル オフガスの増大が問題として残る.

さて, 実際に LNG を空洞に貯蔵した場合には空洞は ほとんどが液体で, 一部が気化して満たされているであ ろう。この場合，液体あるいは気体と空洞表面との間で 熱伝達が行われるので気体あるいは液体の温度は必ずし もそのまま岩盤に伝わるわけではない、いまこれを1 つの抵抗とみて，この抵抗に等しい厚みに見合う岩盤を 空洞表面にさらに付加して, 熱伝導がそこから行われる とするいわゆる “表面熱抵抗の等価の厚さ”9) を考えて みる。これは一般に固体表面の粗さや気体または液体の 流速の影響を受けるが，等価の厚さは実験の結果をもと に理論值を修正するために求めるものであるので, 得ら れた值を用いて逆に理論值を修正すれてば実際の現象にか なりの近似ができるものと考えられる．さて，等価の厚 さ $\delta$ は, 著者らが別の実験によ一て求めた結果 ${ }^{6)}$, 気体 と岩盤表面間では $\delta=1.0 \sim 1.2 \mathrm{~cm}$ 程度, 液体と岩盤表 面間では $\delta$ はほぼ 0 とみなせることがわかった。したが
って実用上は（実際の現場に即した大きなモデル を考える場合には）気体と岩盤，液体と岩盤の両 方の場合について等価の厚さを無視してもほとん ど温度分布の值に影艟を及ぼさないと考えられ る.

\section{3. 空洞周辺の応力解析}

\section{（1）岩石の強度および熱物性值}

低温下の岩石の強度や熱物性值は温度とともに その值を異にする。亦た，実際には地下水の影響 によって岩盤は湿潤状態にあると考えられる。し たがって低温下における湿潤状態の岩石の強度や 熱物性值が必要となる.これらの值については, 著者が 別の実験によってすでに求めているので2),4),5)その值を 本解析で使用した.それらをとりまとめたものが 表一1 である。

\section{（2）塑性領域の判定法}

岩盤内の破壊条件については種々の考え方があるが, ここでは Mohr の破壊包絡線説に従うものと考える.

寸なわち, 岩石内に生じている最大主応力が引張态力 で, しかもその值が岩石の一軸引張強さ $S_{t}$ よりも大き ければその点は引張破壊するものと考え, 最大主応力が $S_{t}$ よりも小さければその点に生じる最大主応力と最小 主応力を直径とする円が, $S_{t}$ を頂点とし, 一軸圧縮強 さ $S_{c}$ と原点とを直径とする円に接するいわゆる Mohr の応力円包絡線（図一11 参照）とに接するか交わるか 寸れば破壊するものと考える。これを式で表わすと次の

表一1本解析に用いた岩石の物性值（湿潤状態）

\begin{tabular}{|c|c|c|c|c|c|}
\hline $\begin{array}{c}\text { 温度範囲 } \\
\left({ }^{\circ} \mathrm{C}\right)\end{array}$ & $\begin{array}{c}\text { 線膨張係数 } \\
\left(1 /{ }^{\circ} \mathrm{C}\right) \\
\times 10^{-6}\end{array}$ & $\begin{array}{c}\text { 弾性係数 } \\
(\mathrm{MPa}) \\
\times 10^{-5}\end{array}$ & ポアソン比 & $\begin{array}{c}\text { 王縮強度 } \\
(\mathrm{MPa})\end{array}$ & $\begin{array}{r}\text { 引張强底 } \\
(\mathrm{MPa})\end{array}$ \\
\hline $20 \sim \quad 10$ & & 0.484 & 0.25 & -163.7 & 7.7 \\
\hline $10 \sim \quad 0$ & 15.1 & 0.484 & 0.25 & -163.7 & 7.7 \\
\hline $0 \sim 10$ & 14.9 & 0.485 & 0.25 & -164.4 & 9.3 \\
\hline$-10 \sim-20$ & 14.5 & 0.485 & 0.25 & -165.5 & 10.2 \\
\hline$-20 \sim-30$ & 14.0 & 0.486 & 0.25 & -167.7 & 10.9 \\
\hline$-30 \sim-40$ & 13.6 & 0.486 & 0.25 & -170.6 & 11.4 \\
\hline$-40 \sim-50$ & 13.2 & 0.487 & 0.24 & $\ldots 174.2$ & 11.9 \\
\hline$-50 \sim-60$ & 12.7 & 0.487 & 0.24 & -178.3 & 12.2 \\
\hline$-60 \sim-70$ & 12.3 & 0.488 & 0.21 & -182.2 & 12.4 \\
\hline$-70 \sim \quad 80$ & 11.9 & 0.488 & 0.24 & $\cdots 186.1$ & 12.6 \\
\hline $80 \sim 90$ & 11.4 & 0.489 & 0.24 & -189.9 & 12.9 \\
\hline $90 \sim 100$ & 11.0 & 0.489 & 0.23 & -193.8 & 13.0 \\
\hline $100 \sim 110$ & 10.6 & 0.490 & 0.23 & -197.7 & 13.2 \\
\hline$-110 \sim-120$ & 10.1 & 0.490 & 0.23 & -201.6 & 13.4 \\
\hline $120 \sim 130$ & 9.7 & 0.491 & 0.23 & -205.5 & 13.5 \\
\hline$-130 \sim-140$ & 9.3 & 0.491 & 0.23 & -209.4 & 13.7 \\
\hline$-140 \sim-150$ & 8.8 & 0.491 & 0.22 & -213.2 & 13.9 \\
\hline$-150 \sim-160$ & 8.4 & 0.492 & 0.22 & -217.2 & 14.0 \\
\hline$-160 \sim-170$ & 8.0 & 0.492 & 0.22 & -221.1 & 14.2 \\
\hline
\end{tabular}




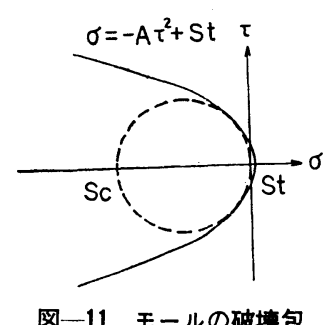

ようになる。

(1) $\sigma_{1}$ が引張応力で $\sigma_{1}$ $\geqq S_{t}$ ならばその点は破壊 する.

$$
\text { (2) } \begin{gathered}
\sigma_{1}<S_{t} \text { のとき } \\
P \geqq S_{t}-A k^{2}-\frac{1}{4 A}
\end{gathered}
$$

絡線

$$
\text { 加 }\left\{\begin{array}{l}
P<S_{t}-\frac{1}{2 A} \cdots \cdots \\
\left(S_{t}-P\right)^{2}-k^{2}>0
\end{array}\right.
$$

(i ) 式 (5)，(6)，(7) を同時に満たすならばその点 は破壊する。

(ii ) $P<S_{t}-\mathrm{A} k^{2}-\frac{1}{4 A}$ ならばその点は破壊しな い.

ただし， $\sigma_{1}, \sigma_{3}$ : 最大および最小主応力

$$
\begin{array}{r}
S_{c}: \text { 一軸圧縮強度 } \\
S_{t}: \text { 一軸引張強度 } \\
P=\frac{\sigma_{1}+\sigma_{3}}{2}, k=\frac{\sigma_{1}-\sigma_{3}}{2}, \\
A=\left(\frac{\sqrt{S_{t}}+\sqrt{S_{t}-S_{c}}}{\sqrt{S_{c}}}\right)^{2}
\end{array}
$$

応力解析にあたっては後述のように有限要素法を用い たが，熱応力のためすべてが引張応力で破壊している.

この場合三角形分割要素内の重心における互いに值角 な 3 つの主応力のうち 1 方向の主応力のみが引張破壊し ている場合には三角形要素内はその方向に薄いせんべい を重ねたように破壊していると考えられ，破壊しない主 応力方向では弾性体としてふるまうと考えられるので, ここではこのような三角形要素の領域を塑性領域とよぶ こととし，3つの主応力とも破壊している場合を破壊領 域とよぶことにし両者を区別している.

\section{（3）応力解析の方法}

ここでは等方性弾性岩盤の地山を想定し, 被り 100 $\mathrm{m}$, 值径 $5 \mathrm{~m}$ の単一円形空洞を掘削し貯蔵した場合に ついて地山の側庄係数, 風化係数を考慮して塑性領域の 範囲に及ぼす影響について検討している．解析には有限 要素法を用い，塑性領域には No Tension 法を適用し 逐次破壊を考慮した解析在行った。 な抢ここでは平面ひ ナ゙み問題として解析している.

a) 側圧係数および風化係数

側生倸数は次式で与えられるものとする。

$$
\lambda_{0}=\frac{P_{h}}{P_{v}}
$$

ただし, $P_{h}$ : 水平㤂力, $P_{v}$ : 鉛值応力, $\lambda_{0}$ : 側庄係数

風化係数は次式で与えられるものとする.

$$
w=\left(\frac{v_{P}}{V_{P}}\right)^{2}
$$

ただし, $v_{P}$ : 地山の弾性波伝播速度

$V_{P}:$ 試料の弾性波伝播速度

また, 岩盤の強度については風化倸数を用いて次のよ うに求める.

$$
\begin{aligned}
& S_{s c}=w S_{c} \\
& S_{s t}=w S_{t}
\end{aligned}
$$

ただし， $S_{c}$ : 試料の一軸圧縮強度

$S_{s c}:$ 淮岩盤圧縮強度

$S_{t}:$ 試料の一軸引張強度

$S_{s t}:$ 淮岩盤引張強度

上式のとおり，ここでは風化係数を地山岩盤の強度の 大きさを表現する係数として用いることとする.

b) No Tension 法

土や砂のように岩石に比べると一般に強度がきわめて 小さく, したがって引張力に対しては抵抗し得ないが, 圧縮力にはある程度耐えてその力を伝達し得るといらい わゆる No Tension 材料に対する応力解析の方法の5 ち最近よく用いられるものに異方性解析法と No Tension 法の 2 つがある ${ }^{10)}$.

異方性解析法は収束性が遅くまた収束が保証されない 欠点をもっている.これに比べ No Tension 法はZienkiewicz らが提案している解析法 ${ }^{11)}$ で収束が速くしか も収束する.

本論文では逐次破壊を考慮して解析を行っているが, 前述の破壊判定により塑性領域, 破壊領域が生じた場合 には，この領域では破壊を生ぜしめた応力方向には引張 力をもはや伝え得ないものとして，これらを節点外力に 置き換え引張応力がほぼ零になるまで繰り返し計算を行 った. 計算の手順を 図一12 に示した.

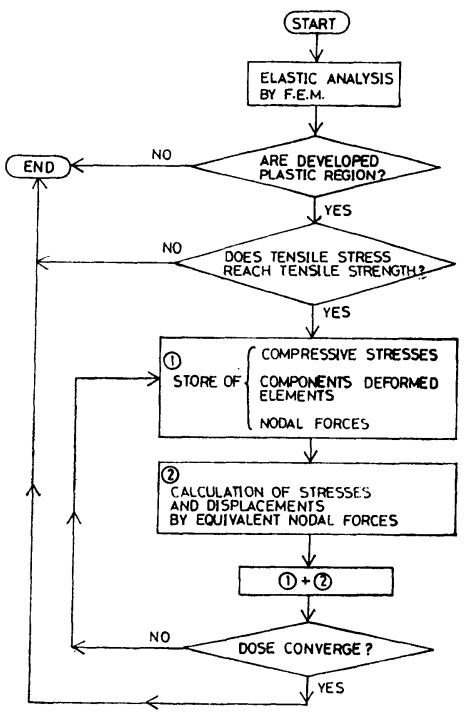

図一-12 No Tension 法による計算手順 


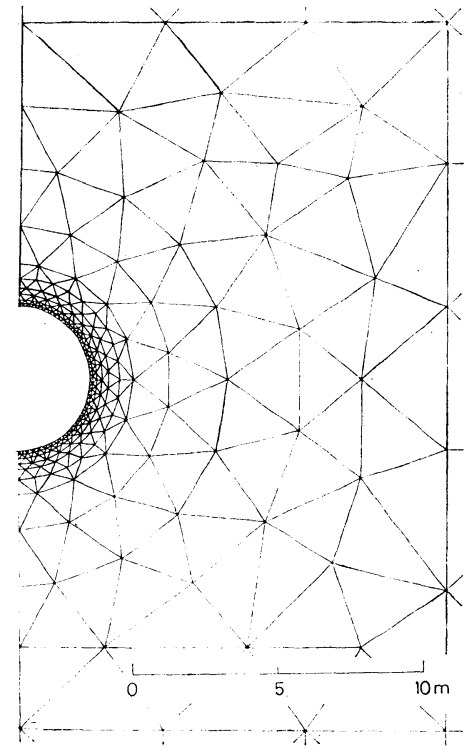

図一13 本解析で用いた要案分割の一部

\section{（4）応力解析の結果および考察}

解析には前述のとおり有限要素法を用いたが空洞に影 響を及ぼさない遠い距離に境界をとる必要がある。今回 は $5 \mathrm{~m}$ の空洞に対し, 空洞から水平, 鉛直下それぞれ $100 \mathrm{~m}, 50 \mathrm{~m}$ に境界をとって解析した. 有限要素法では すべての要素にかかわるつり合い方程式を解いて応力を 求める. しかも今回の計算のように従来の応力のほかに 熱応力が重疊される計算では要素ごとに異なる温度とそ の温度に応じた強度, 弹性変形定数, 熱定数等を絶えず 入れ換えていく必要がある.あまり細かく要素を分割す ると記憶容量の限界や計算時間の長大化する問題が生じ る.したがって許される範囲内で要素を大きくとる必要 がある.一方前述のように温度分布計算では岩盤のよう に熱伝導の悪いものでは要素を細かくとる必要がある.
以上のように温度分布計算と応力計算とでは求める性 格が違うので今回は温度分布の分割要素をそのまま応力 解析に利用することができなかった。

空洞周辺の要素分割の一部を 図一13 に示した.ここ では次の 2 段階に分けて解析を行うこととする.

\section{a) LNG 貯藏前}

まず LNG 貯蔵前には 熱応力は発生せず地山の応力 のみである. 本来は空洞掘削時の発破によるゆるみ領域 が予想されるがここでは考慮しない。

この場合の応力分布を 図一14 (a) (c) に示した. す なわち, それぞれ側圧係数の違いによる空洞周辺の最大 および最小主応力方向線図として示している.これらの 図から $\lambda_{0}=0$ の場合には 空洞の上下端 およびその近傍 で引張応力が発生していることがわかる.この值は最大 值が $P_{v}$ の絶対值に等しく $26 \mathrm{kgf} / \mathrm{cm}^{2}(2548 \mathrm{kPa})$ で あるが花崗岩の引張強度の約 $1 / 3$ 程度であり,ここには 破壊が生じない，次に水平軸に沿う応力分布をみると， 接線方向の応力 $\sigma_{t}$ は水平で最大圧縮応力となっており, これらの值は側圧が小さいほど大きい值をとることがわ かる. 特に $\lambda_{0}=0$ のときには $\sigma_{t} \fallingdotseq 3 P_{v}$ となるが, ここ では約 $80 \mathrm{kgf} / \mathrm{cm}^{2}(7840 \mathrm{kPa})$ の圧縮応力なので破壊 は生じない，その他のあらゆる点について 3. (2) で述 べた破壊の判定条件を適応させた結果, LNG 貯蔵前に は, 側圧係数 $\lambda_{0}=0,0.5,1.0$ いずれの場合も空洞は安 定していると考えられる.

\section{b) LNG 貯藏後}

空洞表面は前述のとおり $-162^{\circ} \mathrm{C}$ (一定) に保たれる ものと仮定する. 図一5 (b) からわかるように, 温度勾 配は初期の時間に非常に大きい。空洞周辺には初期の時 間から熱応力によって引張応力が発生し始め, この値は 時間とともに大きくなってゆくが空洞表面近くの分割要 素寸法を $10 \mathrm{~cm}$ として（奏用上この程度でよいと思わ れる)，1 分ごとに変化した 温度分布と，それに対応し た強度, 弾性変形定数, 熱定数

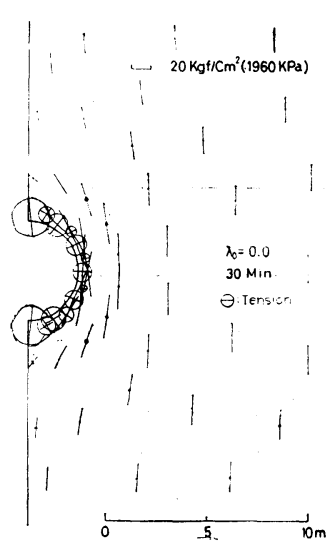

(a) $\lambda_{0}=0.0$

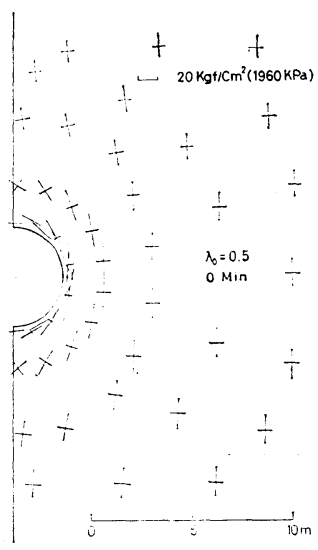

(b) $\lambda_{0}=0.5$

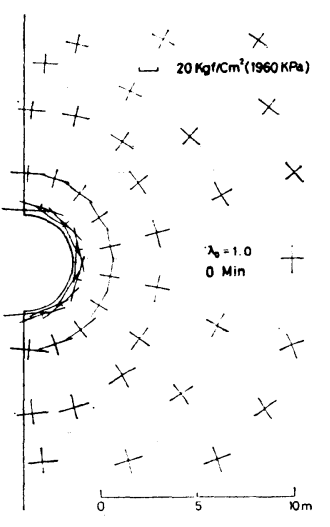

(c) $\lambda_{0}=1.0$
図一14 LNG 貯葴前における空洞周辺の最大および最小主応力方向線図
等を入れ換えて種々の計算を行 つた結果空洞に最も近い分割要 秦が破壊してくるのは約 30 分 後であることがわかった。

図一15（a)〜(c) はそれぞれ 30 分後における側圧の違いに よる最大および最小主応力方向 線図である。 また，図一16 は 水平軸に沿う半径方向の応力 $\sigma_{r}$ と接線方向の応力 $\sigma_{t}$ を側圧の 違いによって, かっ貯藏前と貯 蔵後 30 分について比較をした ものである.これらの図から側 

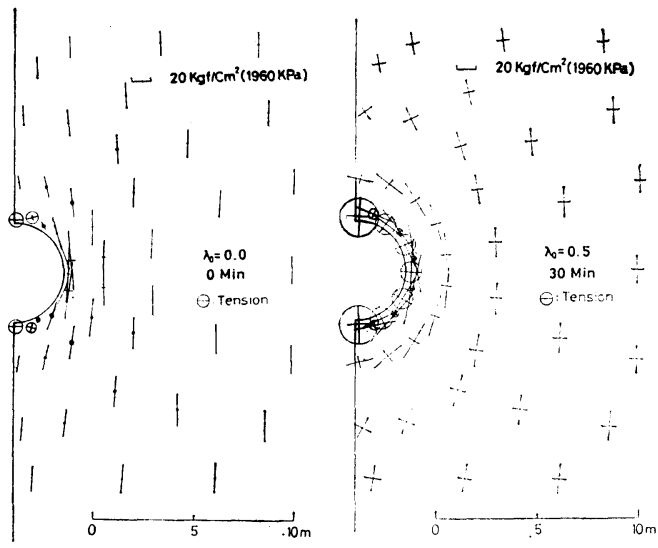

(a) $\lambda_{0}=0.0$

(b) $\lambda_{0}=0.5$

图-15 LNG 舵蔽 30

圧係数 $\lambda_{0}$ の值にかかわらず空洞から約 $20 \mathrm{~cm}$ 以内のと ころでは応力分布はよく似ている．また貯蔵前には図一 14 (b)，(c) からわかるように， $\lambda_{0}=0.5$ および 1.0 の 場合には引張応力の発生がみられなかったが, 貯蔵後に はいずれの図においても熱応力のため非常に大きな引張 応力が接線方向に発生していることがらかがえる。しか し，表面から遠ざかるにつれ温度の影響がなくなってく ると応力分布は当然のことながら貯蔵前のそれに近づい てゆく

以上の結果から，熱応力の影響は非常に大きく，温度 分布が初期の段階において，側圧係数のいかんにかかわ らず空洞周辺に沿って約 $10 \mathrm{~cm}$ の範囲で同心円状に塑 性領域が発生することがわかった．次にすでに述べたと おり, 空洞周辺の温度分布は空洞の直径にかかわらず 1 年後にほぼ準定常になり，その後も破壊は進展していく と考えられるが非常に緩慢であると考えられるのでここ では参考のため一応 1 年後における塑性領域を述べるこ ととする. 比較のため, 図一5(b) から，(1) 1 年後の温 度分布を用いてすなわち非現実的ではあるが地山内に瞬
間的に 1 年後の温度分布が与え

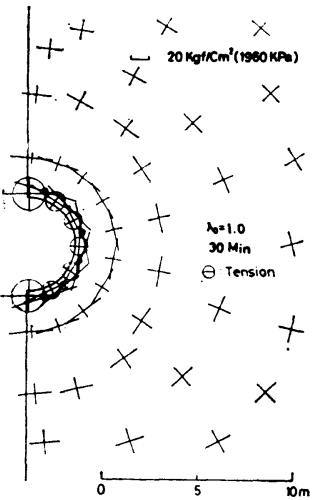

(c) $\lambda_{0}=1.0$ られたと仮定して解析を行った 場合と，(2)まず 30 分後に破壊 が始まることをふまえ，これに 続いて時間の経過とともに逐次 に破壊が起こっていくことを考 虑しながら 1 年後まで解析を行 った場合とについて両者の塑性 領域の違いを比較したものが図 一17である（図は $\lambda_{0}=0.5$ の 場合のものであるが，破壊はす べて熱応力によるものであるの で $\lambda_{0}$ を変えても塑性領域の範 囲はほぼ同じとなる)。ただし， 塑性領域が順次生じた場合にはマイクロクラックの発生 等によって熱の移動が以前と異なることが予想される が，ここでは熱の移動は変化しないものと仮定してい る.図一17から，逐次破壊を考虑した場合は塑性領域が 約 $6 \mathrm{~m}$ であるのに対し，そうでない場合は $10 \mathrm{~m}$ の範 囲であり，約 2 倍の差があることがわかる.

以上のことから, 多小学力を要するが逐次破壊を考虑 した解析を行う方が時間的概念が考虑されているのでよ り実際の現象に近いと考えられる。

次にすでに 温度分布のところで述べたように，直径 $5 \mathrm{~m}$ の空洞を 水平方向に 直径の 5 倍（空洞表面間 距離 $25 \mathrm{~m}$ ) 離して 双設空洞とした場合について（図一8 参 照） 1 年後の塑性領域を求めたものが 図一18 である. この図から直径の 5 倍では隣接空洞からかなりの影響を 受けることがわかる．そこで空洞の 1 年後の温度分布か ら（図一5(b) 参照）低温の影響が及ばない最小距離は 空洞表面から約 $17 \mathrm{~m}$ であったのでここでは空洞表面間 隔を直径の 7 倍の $35 \mathrm{~m}$ として解析を行った. 1 年後の 塑性領域を求めたものが 図一19 (a)，(b)，(c) である。

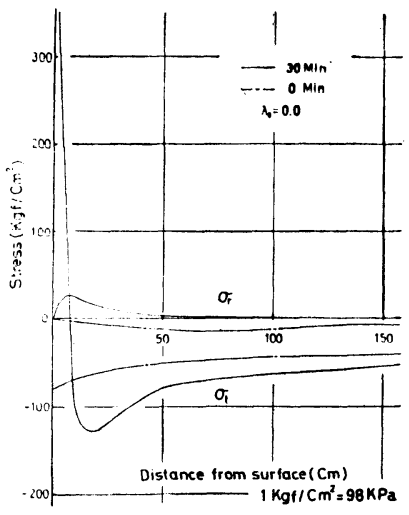

(a) $\lambda_{0}=0.0$

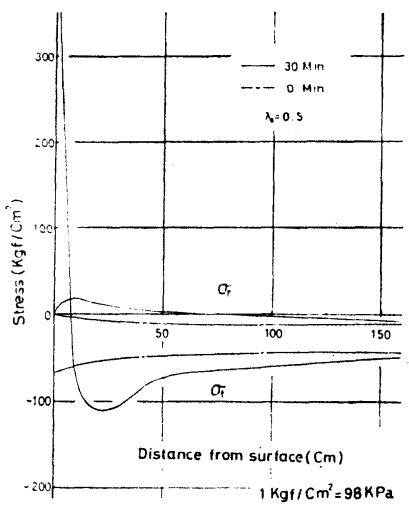

(b) $\lambda_{0}=0.5$

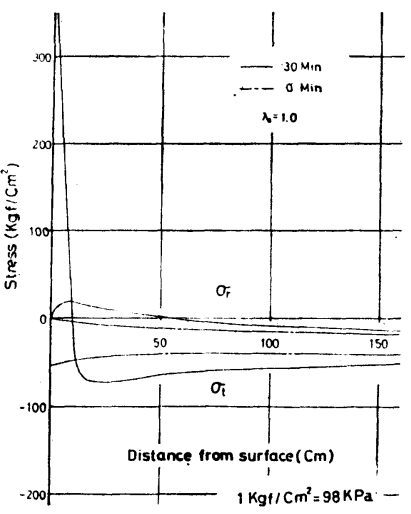

(c) $\lambda_{0}=1.0$ 


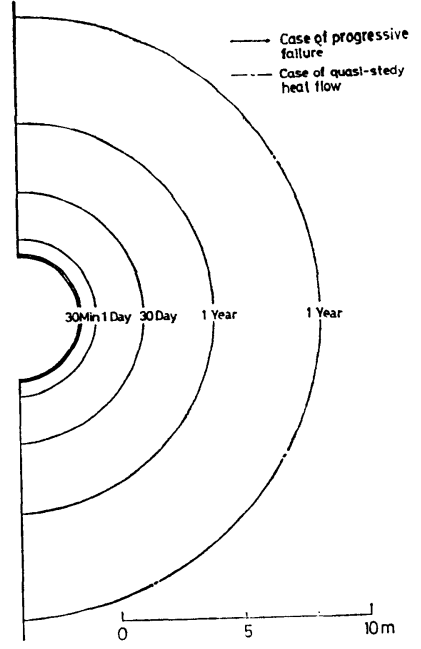

図一17逐次破䯚を考虑して解析した堣合と 考虔しない场合とによる LNG 貯藏 1 年後の空洞周辺の塑性領域の比较

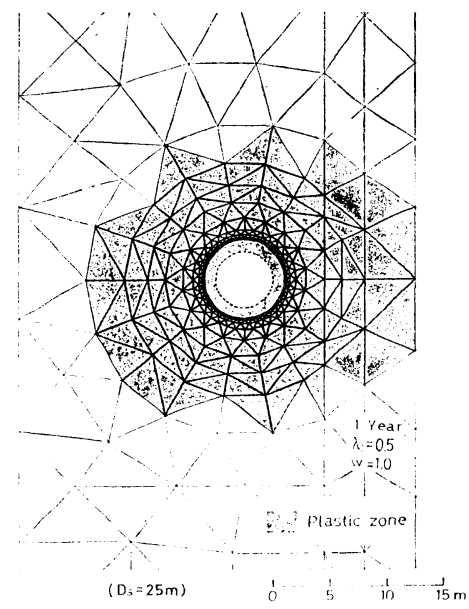

図一18空洞間隔を直径の 5 倍 $(25 \mathrm{~m})$ とした 場合の LNG 貯藏 1 年後の望性領域 ただし，(a)，(b)，(c) はそれぞれ風化係数 w の值が 1.0,0.6,0.3 の場合を示している. これらの図から塑性 領域の範囲がそれぞれおよそ $6 \mathrm{~m}, 9 \mathrm{~m}, 11 \mathrm{~m}$ であり, 特に（c）では水平軸方向で約 $12 \mathrm{~m}$ にまで達してお り，風化係数が小さいほど隣接空洞の影響をかなり受け ることがらかがえる.

以上の結果から地質の状態によって空洞間隔を十分考 慮しておく必要があることがわかる。また，現在の LN G 貯蔵方式では中程度と考えられる 6 万 $\mathrm{k} l$ を貯藏する 場合, 直径がそれぞれ $10 \mathrm{~m}, 5 \mathrm{~m}$ の場合, $200 \mathrm{~m}$ の長 さとするとそれぞれ 3 本および 15 本の空洞が必要とな り，300 m の長さとするとそれぞれ 2.5 本および 10 本 必要となる．この場合空洞間隔をできるだけ縮めるには パーライト粉等による断熱材を用いるかあるいはヒータ 一を用いる方法が考えられるが，前者については 図一9 でみられるとおり 1 年後には効果がないことがわかって いるのであまり期待ができない，後者つにいて 図一10 をもとに空洞周辺 $1 \mathrm{~m}$ を岩粉層で覆い, 岩盤と岩粉層 の境界にヒーターを用いた場合について解析を行った. 1 年後の結果を図一20 に示した. 図中の $\sigma_{r}, \sigma_{t}$ はそれ ぞれ水平軸倍う半径方向の応力および接線方向の応力 を示している. 岩盤内には引張応力が発生しておらず, $\sigma_{t}$ の值も空洞から $4 \mathrm{~m}$ 離れると急激に小さくなること がわかる.したがってヒーターを設けた場合は空洞は安 定すると推察される. ただし, 前述のとおりヒーター設 置によるボイルオフガスの増大が問題として残る.

今回の結果から, LNG を空洞内に貯蔵する場合には 熱応力による引張応力が主体となって温度分布が淮定常 となる 1 年後まで塑性領域が進展してゆくことがわかっ た. したがってこれらに対処する工夫すなわち空洞周辺 の断熱の問題ならびに液もれ，ガスもれの防止のための 安全性に対する工夫すなわち空洞表面にたとえば特殊合

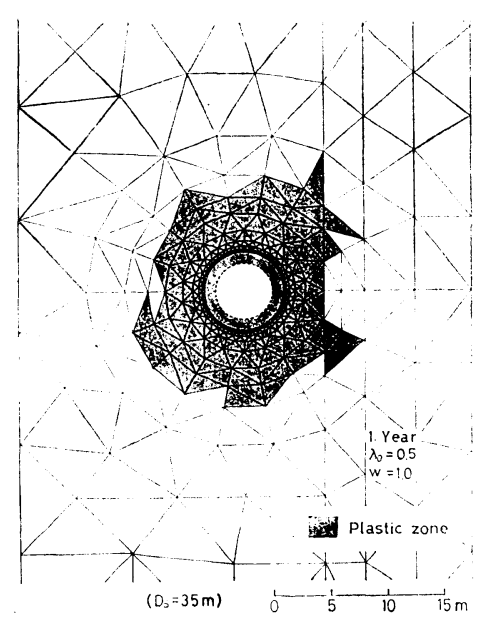

(a) $w=1.0$

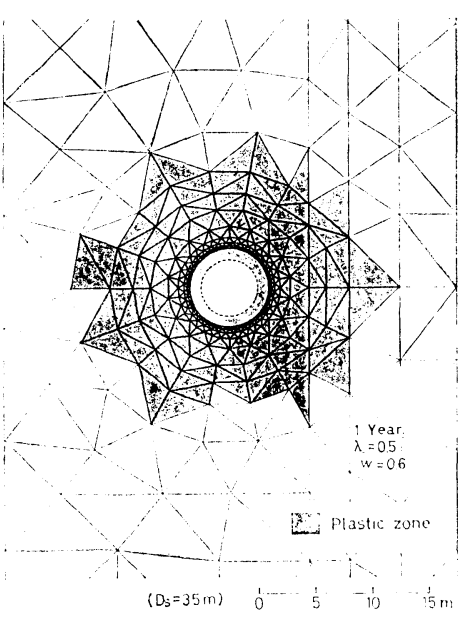

(b) $w=0.6$

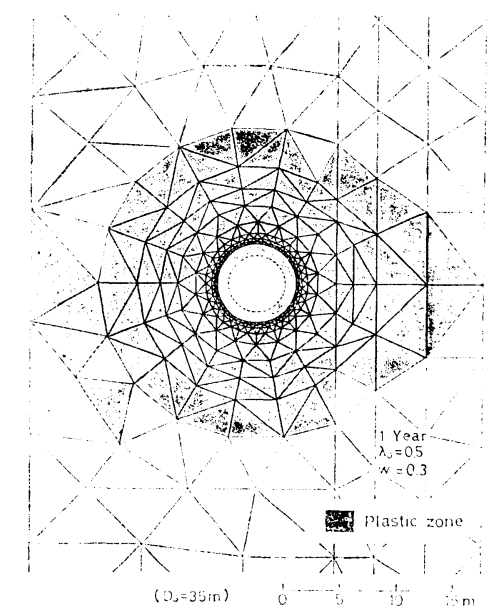

(c) $w=0.3$

図一19 空洞間际を直径の約 7 倍 (35 m) とした罚合の LNG 貯藏1 年後の望性領域の比較 


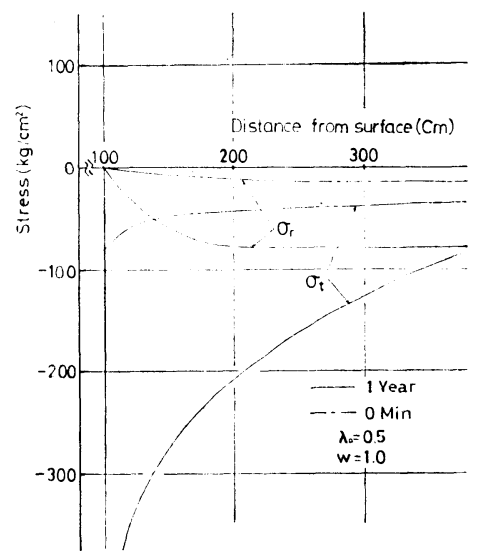

図一20ヒーターを用いた場合の水平軸方向 における空洞周辺の応力分布

金製の薄いメンブレンを用いることが望ましいことや低 温に強い物質による空洞表面保護等がなされなければな らないことがわかった. 今回は紙面の都合上, 種々の要 因が塑性領域の範囲に及ぼす影響について述べ得なかっ たがこれらは別の機会に報告したいと考えている.

\section{4. 結}

LNG を地下の岩盤内空洞に直接貯蔵する場合を想定 して解析し考察した結果について述べた. 今回得られた 結果を要約すると次のとおりである.

（1）地下岩盤内空洞周辺の温度分布を要素分割法を 用いて求め得ることを示した.この場合, 空洞の形状が 円形で単一の場合は矩形要素分割が，また形状が複雑で あったり複数の場合は三角形要素分割が便利である.

（）空洞の直径が大きいほど空洞表面の温度の影響 が大きい。しかし，空洞の直径が今回解析を行ったよう な $2 \sim 10 \mathrm{~m}$ の範囲ではいずれの場合も約 1 年後にはほ ぼ準定常とみなせるような温度分布を示す.

（3）被りが $100 \mathrm{~m}$ の地下岩盤内に直径 $5 \mathrm{~m}$ の空洞 を開削した場合，LNG を貯蔵前は空洞は安定している が, 貯蔵後は 30 分で熱応力による塑性領域が約 $10 \mathrm{~cm}$ の同心円となって発生する. その後塑性領域は逐次広が ってゆき，ほぼ準定常とみなせる 1 年後には約 $6 \mathrm{~m}$ の 範囲にまで広がる。
さ $1 \mathrm{~m}$ のパーライト粉の層を設けた場合には 1 か月後 までその効果が現われるが，1 年後には設けなかった場 合と同じになる．またもら一つの方法として空洞の周囲 にはじめから岩粉層を $1 \mathrm{~m}$ 設けておき，岩盤との境界 に $60^{\circ} \mathrm{C}$ のヒーターを設けた場合には空洞は安定する. ただし，ヒータ一設置によるボイルオフガスの増大が問 題として残る。

（5）複数空洞の場合には塑性領域の発生範讲に風化 係数（寸なおち地山岩盤の強度の大きさ）がかなり影響 在及ぼす。

本研究の遂行に際し，愛媛大学工学部 八木則男教授 のご助言を賜わり，海洋丁学教室海洋資源丁，学講座諸氏 のご協力をいただいたことを記し厚く感謝する。

な㧍数值㴻算には九大大型計算機センターの FACO. M M-190 および愛媛大学計算機 センターの FACCM 230-28 を使用した。

\section{参 考 文 献}

1）稲田善紀・八木則男 : 液化天然ガスの 地下貯蔵に関する 基礎的研究——特に低温領域における 岩石の挙動につい て一，土木学会岩盤力学委員会第 12 回岩盤力学に関す るシンポジウム講演概要, pp. 86〜90, 1979.

2）稲田善紀・八木則男：低温の影響をを受けた岩石の力学特 性, 材料, 28, 313, pp. 979 985, 1979.

3）稻田善紀・八木則男：液化天然ガスの 地下貯蔵に関する 基礎的研究——特に空洞周辺に扔ける 温度分布について 一, 上木学会岩船力学委貟会第 13 回岩盤力学に関する シンポジウム講演論文集, pp. 41〜 45, 1980.

4）稲田善紀・八木則男：極低温下における㞸石の力学特性, 材料, 29, 327, pp. 1221 1227，1980.

5）稲田善紀・八木則男：低温下に㧈ける罗不の熱物性值, 材料, 29, 327, pp. 1228 1233, 1980.

6）稻田善紀・重信 純：液化天然ガスを地下岩盤内空洞に 泞蔵した場命の空洞周辺の温度分布， H本鉣業会誌，99， 1140 , pp. $179 \sim 185,1983$.

7）液化天然ガス用眝槽保安調查委員会：LNG 地下式䝪槽 指針, p. 27, 1979.

8) Carslaw, H.S. and J.C. Jaeger : Conduction of heat in Solids, Oxford at the Clarendon Press, pp. 335 $336,1959$.

9）拔山四郎：熱，養賢堂. p. 45, 1969.

10）川本朓万・林 正夫：地盤工学に扔ける 有限要素解析, 培風館, pp. 112 115, 1978.

11) Zienkiewicz, O.C., S. Valliappan and I.P. King: Stress Analysis of Rock as a No Tension Materials, Geotechnique, 18, pp. 56 66, 1968.

12）前掲 8), p. 282

(1983.5.19 • 受付)

（4）熱を遮断する方法の 1 つとして空洞の周辺に厚 